\title{
Intertextuality and National Literatures in the Context of Comparative Literature Research
}

\author{
ANNELI MIHKELEV
}

Abstract. $20^{\text {th }}$-century literary theory discovered another possible way for world literature to exist and include all national literatures and cultures: the concepts of 'intertextuality' and / or 'multimediality' mean that contacts between cultural texts work as a network and this network includes national literatures, i.e. intertextuality and / or multimediality creates world literature. All European cultures have common sources from Ancient Greece and Rome and the Bible, which means that translations have played a very important role in European culture. Authors who use other literary works also interpret them and this gives new meaning to their works. The term 'dialogue', in Mikhail Bakhtin's sense, plays a crucial role in the intertextual process. If we speak of influences, dialogue is not the crucial phenomenon on the contrary; influence is a more hierarchical phenomenon. It seems that intertextuality, especially postmodern intertextuality, avoids hierarchical communication, instead working with the dialogical relationship between the author, text and reader. Intertextuality and/ or multimediality have a great potential to connect different texts and literatures in the world. The dialogical relationships between different texts and authors are significant because the postmodernist era destroyed hierarchies, or at least tried to destroy them. This means that all literatures, including small languages and literatures, have the possibility of being world literature, offering the opportunity for comparative literary research. The paper analyzes several poets and poems from different small countries. The Irish poet W.B. Yeats was an innovator in Irish poetry and drama. He combined national myths and fantasy with a symbolist style and the main pathos in his poetry is connected with the freedom of Ireland. Finnish poet Eino Leino used very old national motifs in his poetry, and there is a tension between the older romantic tradition and the contemporary styles he used. There are mystical elements and intertextual connections from the Finnish epic Kalevala, as well as from fairy-tales and folk songs, in Leino's poetry. Leino was also influenced by the German poet Heinrich Heine. Eino Leino was also the Estonian poet Gustav Suits' friend and he influenced Suits' poetry. Estonian poets Heiti Talvik's poetry represents how intertextuality makes possible ambivalence meaning, the poet uses biblical myths in the new context. The contemporary Estonian prose writer and poet Ene Mihkelson refers to the Bible in her poetry and novels. She uses one of the common sources of European culture, but at the same time she speaks of Estonian history and 
Intertextuality and National Literatures in the Context of Comparative Literature Research

destiny or, in other words, she uses the Bible to describe her national culture, describing and learning via another culture. All these examples demonstrate a very important aspect of the textual relationship: text memory and the great potential to connect different texts intertextuality and / or multimediality.

Keywords: intertextuality, multimediality, transtextuality, influence, symbolism, myths, memory, modernist poetry

\section{Intertextuality and Influence}

The aim of this paper is to discuss and demonstrate how intertextuality and / or multimediality, i.e. the connections between cultural texts at different levels, have the potential to connect different literatures from different countries and nations and languages in a single world literature.

Goethe wrote about world literature (Weltliteratur) in 1827 in his diary, and he used that term in opposition to aggressive and culturally isolated nationalism, which was dominant in $19^{\text {th }}$-century Europe. Goethe's ideal literature expressed an opposition to wars and national isolation, and Goethe believed that national literatures would become a meaningless concept, that the new epoch would be a time of world literature. Of course, a world literature is possible only via translation, because there are many languages and national literatures that would create a world literature.

It is interesting that another German researcher, Johann Gottfried Herder (1744-1803), prior to Goethe, proposed something even more ideal. Katie Trumpener has written:

[A]comparative paradigm and an investigative spirit that belong to the slightly earlier moment of the Enlightenment and late-eighteenth-century sentimental enthusiasm [...] Herder's work of the 1770s thus encompasses not only his influential essay on Ossian, Shakespeare, and Hebrew poetry but his comparative ethnographic collection, Stimmen der Völker in Liedern [Voices of the Peoples in Songs] (1778-79). At a moment when most European ballad-collecting is implicitly or explicitly nationalist, Herder collects and juxtaposes songs and oral materials from all over Europe, from Greece to Greenland, with special attention to often-overlooked areas like the Baltic. (Trumpener 2006: 185)

Herder's ideas from the $18^{\text {th }}$ and $19^{\text {th }}$ centuries reflected not only the destiny and freedom of the individual, but also the destiny and freedom of every nation. The most important aspect of Herder's idea was that there were many nations in Europe, including small nations. 
MIHKELEV

In the $20^{\text {th }}$ century T.S. Eliot discussed, in the essay The Unity of European Culture (1947), great poetry and poets. Eliot believed that English poetry was very good because it was a collection of different European sources, that is English poetry is synthesized poetry. Although Eliot did not use the term intertextuality, he wrote about different poets from different countries - Yeats, Rilke, Poe and others - and how these poets wrote great poetry. The main idea in this article is that all of these great poets and great poetry would not exist without other cultures and literatures, without assimilations and influences, and without original sources from other countries (Eliot 1997: 199-201).

At the same time, all European cultures have common sources from Ancient Greece and Rome and the Bible, which means that translations have played a very important role in European culture. Eliot used the term 'influence', giving the main role to authors who had been influenced by other authors or literary works. The term 'intertextuality' also gives an important role to the reader, who has to recognize the connection between different texts, and that reader has to interpret these intertextual connections. Authors who use other literary works also interpret them and this gives new meaning to their works. The term 'dialogue', in Mikhail Bakhtin's sense, plays a crucial role in the intertextual process. If we speak of influences, dialogue is not the crucial phenomenon; influence is a more hierarchical phenomenon as, for example, Harold Bloom explains in his book The Anxiety of Influence (1973) where he uses the metaphor of father-son inheritance and Freud's theory of the Oedipus complex (Bloom 1975: 11, 94-95). According to Worton and Still, Bloom's "theory of influence as an articulation of aggressive-defensive narcissism is often attacked (notably for its phallocentrism)" (Worton, Still 1993: 27). And Mary Orr has stated that "...influence, so strongly associated with authority figures, is automatically oppressive to newcomers struggling against an impossible weight of heritage that they can neither join nor follow, whether as writers or critics" (Orr 2003: 62). It seems that intertextuality, especially postmodern intertextuality, avoids hierarchical communication, instead working with the dialogical relationship between the author, text and reader.

According to Julia Kristeva, the inventor of the term 'intertextuality' in the 1960s, and her predecessor Mikhail Bakhtin, "any text is constructed as a mosaic of quotations; any text is the absorption and transformation of another" (Kristeva 1980: 66). All words and utterances that exist in a given work belong to a language that is already there and are therefore loaded with earlier historical and social meanings. Texts are transformations of other texts, participating in several discourses simultaneously. However, the existing body of literature always remains (ib.). Another theorist Gerard Genette had opinion that 'intertextuality' is an inadequate term: “Today I prefer to say, more sweepingly, 
Intertextuality and National Literatures in the Context of Comparative Literature Research

that the subject of poetics is transtextuality, or the textual transcendence of the text, which I have already defined roughly as "all that sets the text in a relationship, whether obvious or concealed, with other texts" (Genette 1997: 1; see also Worton, Still 1993: 22). Whatever, it seems that $20^{\text {th }}$ century literary theory discovered another possible way for world literature to exist and include all national literatures and cultures: the concept of 'intertextuality' and / or 'transtextuality' means that contacts between texts work as a network and this network includes national literatures, i.e. intertextuality creates world literature: “... in the sphere of textual relations, can be represented by the old analogy of the palimpsest: on the same parchment, one text can become superimposed upon another, which it does not quite conceal but allows to show through" (Genette 1997: 398-399).

Gerard Genette's term 'palimpsest', an ancient document from which some or all of the original text has been removed and replaced by a new text, offers a very good metaphor for contacts between literary texts and literatures: all literary texts are potentially connected and we can compare them. But, most importantly, intertextual relations also create new and usually original meanings, and it is very important to talk about innovations in literature.

\section{Innovative national and international poets}

Eliot wrote about the Irish poet William Butler Yeats (1865-1939), who was an innovator in Irish poetry and drama. Yeats combined national myths and fantasy with a symbolist style and the main pathos in his poetry is connected with the freedom of Ireland. Yeats' cultural and political nationalism was a reaction to the late Victorian world. Yeats' aim was to establish a special and original Irish poetry. Traditional motifs paired with an innovative style were a departure from European mainstream modernist poetry. Yeats' poetry was still innovative and high-styled, while carrying national meaning. This is a paradox: nationalism as a traditional and conservative phenomenon combined with modernism.

Irish mythology, with its heavenly beings, gods and simple peasant culture, creates the tension in Yeats' poetry. The earthly and heavenly, the high and low, are always combined in Yeats' literary works (e.g. The Cold Heaven, 1914). Especially at the end of the $19^{\text {th }}$ century, Yeats used Irish mythology and folklore in his works (e.g. The Stolen Child, 1889; The Man Who Dreamed of Faeryland, 1893; and The Hosting of the Sidhe, 1899). His poems are passionate and full of contrasts (e.g. The Lover Tells of the Rose in his Heart, 1899). The red rose is a symbol of freedom which occurs again and again in Yeats' poems. He 
MIHKELEV

was also involved with occult ideas (Surette 1994: 6-79). Yeats searched for wisdom in old myths and folklore, in tradition. Such old wisdom is cyclical, like the seasons, and it is connected with mythical thinking; rebirth is a motif which connects old pagan mythologies with Christianity, as well as with nations who have the experience of losing freedom and hope to regain it. Yeats' poetry was innovative in the modernist context, in major European countries, when he combined old national traditions with the modernist bohemian life style, and neo-romanticism with symbolism. We can find several intertextual connections with Irish folklore and mythology in Yeats' poetry, but European symbolism influenced his style. The result is great poetry which is not only national but also international, e.g. the poem Leda and the Swan (1923) although there are no direct Irish symbols and myths in the text:

A sudden blow: the great wings beating still

Above the straggering girl, her thighs caressed

By the dark webs, her nape caught in his bill,

He holds her helpless breast upon his breast.

How can those terrified vague fingers push

The feathered glory from her loosening thighs?

And how can body, laid in that white rush,

But feel the strange heart beating where it lies?

A shudder in the loins engenders there

The broken wall, the burning roof and tower

And Agamemnon dead.

Being so caught up,

So mastered by the brute blood of the air,

Did she put on his knowledge with his power

Before the indifferent beak could let her drop?

(Yeats 1990: 104)

Yeats uses Greek mythology, the rape of Leda by the Swan and proper name Agamemnon with the broken wall, the burning roof and tower allude to several tragic events in European history. The poem represents a brutal picture, but the last strophe expresses rhetorically and hopefully the idea that perhaps Leda connects the power and knowledge of the divine Swan (Zeus). The lack of knowledge makes power dangerous, including divine power. Yeats poem demonstrates how intertextuality creates new, original and international meaning.

There are some similarities between Yeats and the Finnish poet Eino Leino (1878-1926). Leino used very old national motifs in his poetry, and there is a tension between the older romantic tradition and the contemporary styles he 
Intertextuality and National Literatures in the Context of Comparative Literature Research

used, mostly new-romanticism (see also Mihkelev 2011) Leino was also the Estonian poet Gustav Suits' friend and he influenced Suits' poetry (see Süvalep 2003). The Estonian researcher Ants Oras has written:

Suits [...] influenced by his friend, the Finnish storm-and-stress genius Eino Leino, he in his first volume of poetry, Elu tuli (The Fire of Life, 1905), poured forth inflammatory, tempestuous verse unlike anything so far written in Estonian. The great commonplaces of freedom, of the right of youth to strike out in new directions - fiery individualism; but also of the right of nations to struggle for their place in the sun - equally fiery patriotism -, were voiced here in magniloquent language and exciting rhythms. (Oras 1963: 9)

The individualism characterizes also Leino's poetry. There are mystical elements and intertextual connections from the Finnish epic Kalevala, as well as from fairy-tales and folk songs, in Leino's poetry. Leino was also influenced by the German poet Heinrich Heine. Mysticism is the most important characteristic of Leino's poetry. The Estonian researcher August Anni feels that the strongest features of Leino's works are its hidden style and language: his style is musical, and its sound is very beautiful. His ballads in the collection Helkavirsiä (Whitsongs, 1903 and 1916) express that musical style best (Anni 1922: 11). Leino's poetry contains a tension between old folk songs and a contemporary modernist style. The old ballads and mysticism, combined with the author's originality, make Leino's poetry modernist: this is the paradox of modernism (c.f. Yeats' poetry above). It seems that modernist art used old motifs and fragments, but the most important thing was to interpret these old motifs in a very individual style, and the personality of the author was very important.

Estonian poet Heiti Talvik (1904-1947) was the member of the circle of writers Arbujad (Logomancers) before World War II. Oras has written about the Arbujad group and Talvik the following:

What the best of theses poets had in common was their anti-materialistic attitude, a strongly marked idealism and a belief in very high standards, ethical as well as artistic. [...] They had had a thoroughly Estonian education, but they were Europeans, intent on the best that Europe had produced, yet sufficiently gifted and original to re-create and develop it in Estonian terms. [...] The conscience and guiding spirit of this group was Heiti Talvik [...], self-lacerating, austere, the most faithful of the clerks, and in the end an apocalyptic visionary foreseeing the horrors, one of whose victims he was destined to become. For him, the poet's greatest task was to impose spiritual order on that chaos whose imminence he felt with exceptional keenness. (Oras 1963: 19) 
MIHKELEV

Talvik's poem Orjade koor (Chorus of Slaves, 1935-1936) from the collection Kohtupäev (The Day of Judgement, 1937) represents how intertextuality makes possible ambivalent meanings:

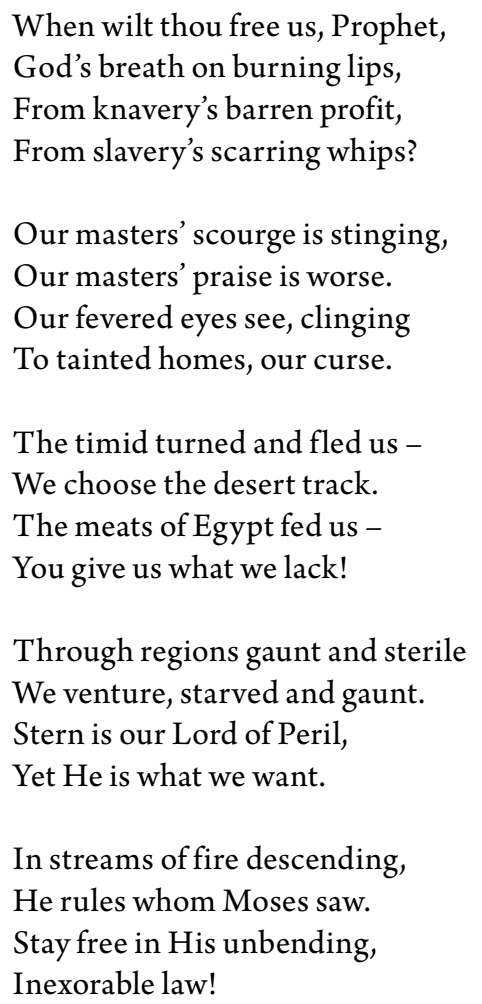

We can read it directly as a poem about Jews in Egypt, how the slaves want to escape to the desert and to be free. But there is also another possibility to interpret that text. If we read the third and the fourth strophes, it is possible that the question arises, do the slaves actually become free: "The meats of Egypt fed us-/ You give us what we lack! [...] Stern is our Lord of Peril, / Yet $\mathrm{He}$ is what we want [...] Stay free in His unbending, / Inexorable law!” (Lange 2002: 107).

Perhaps the real meaning of the poem is that the slaves actually do not want to be free, because they just change the masters. So, the freedom in this poem is just a declaration. That meaning is not written in the poem, it is unsaid, but in relation with written or said meaning they produce possible ironic meaning. At the same time the beautiful meaning of the poem turns ugly.

The contemporary Estonian prose writer and poet Ene Mihkelson (b. 1944) refers to the Bible in her poetry and novels. She uses one of the common 
Intertextuality and National Literatures in the Context of Comparative Literature Research

sources of European culture, but at the same time she speaks of Estonian history and destiny; more precisely, Mihkelson uses the Bible to describe her national culture, describing and learning via another culture. For example, the novel Ahasveeruse uni (The Sleep of Ahasueros, 2001) contains allusions to two myths which are connected with the Bible and the Christian tradition. It is the proper name Ahasueros that referes to the two myths. One of them is from the Old Testament, the Book of Esther, which contains the story of Ahasuerus, the Persian king who married Esther, a Jewish girl, who became the queen. There is also a story of another Ahasuerus, the Wandering Jew. Mihkelson connects and interweaves these old myths to describe national (Estonian) history, her own culture. The meaning of the old biblical myths is transformed, and the Bible connects different nations and histories. Mihkelson's novel and its intertextual connections cannot be seen as literary influences because a dialogical relationship exists between these two texts and also Estonian literature from the $19^{\text {th }}$ century:

The first time that something clicked for me was when I read Villu's Fights. There's a scene there where another Villu surveys the fallen and in the moonlight he sees the face of his Estonian friend, the face of the knight Goswin Herice. The Germans fought on one side, the Estonians on the other, but on occasions it was a brother-kills-brother war too. This sentence latched onto my eye, and in my heart I felt only pain. We've been forest dwellers for a long time, but even on the edge of Europe and further east you can't stay in the forest for ever. When I was looking around manor buildings and parks, I was as much here as there. I didn't even dare speak of how very much there I sometimes felt. So when reading about the Estonian fight for freedom, I was fighting on my own side against myself. Now she started to laugh, as if this train of thought seemed silly to her too.

How must that Priidu with his tongue cut out have felt as the son of a knight and commoner mother. He lived as a free farmer, but he had to think as a serf. At least that was the way Bornhöhe had visualised Priidu, and Villu as well, dying for freedom. Of course, now it's easy to make yourself belong as a German or whatever nationality, if you could just get the corporal punishment out of your memory. (Mihkelson 2001: 90-91; trans. by Miriam McIlfatrick-Ksenofontov)

This excerpt refers to one of the most popular Estonian writers of the $19^{\text {th }}$ century, Eduard Bornhöhe's historical story Villu võitlused (The Struggles of Villu, 1890) and to Estonian history in the context of recent years. Estonian researcher Eneken Laanes has written that Mihkelson's novel "analyses the formation of the trope of 700 years of serfdom in cultural memory and in literature as its medium.” (Laanes 2009: 320) 
MIHKELEV

\title{
Intertextuality as text memory
}

The examples above demonstrate a very important aspect of the textual relationship: text memory. According to Renate Lachmann "the memory of a text is its intertextuality" (Lachmann 1997: 15-16). This means that intertextuality works against forgetfulness in the text, and it does so on different levels. For example, quotations from other texts (from folklore, myths, the Bible etc.) remind us of other texts and the contexts and messages of the texts. Leon Burnett has stressed another very important cultural aspect of intertextuality, the expression of the continuity of existence (Burnett 2002: 44). He explains and concludes that idea as follows:

It sought, if not to deny the existence of the chasm that others had discerned between the present and the past, at least to bridge the gap by establishing new lifelines, new continuities. These continuities were both national and international, both contemporary and historical, driven by an 'active love of literature' that would 'draw the fragile ship of the human word [...] into the open sea of the future'. (Ib. 56-57)

Although Burnett was writing about modernist poetry (Mandelstam, Brodsky et al.), the same idea regarding continuities can explain intertextual relationships: continuity is one of the messages of all of the literary works mentioned above.

\section{Conclusion}

Intertextuality and / or multimediality have a great potential to connect different texts and literatures in the world. The dialogical relationships between different texts and authors are significant because the postmodernist era destroyed hierarchies, or at least tried to destroy them. At the same time, intertextuality works as the memory of the text and expresses the continuity of existence, and it also activates memory in the author and reader. This means that all literatures, including small languages and literatures, have the possibility of being world literature, offering the opportunity for comparative literary research.

\author{
Anneli Mihkelev \\ milenna@hot.ee \\ Tallinna Ülikool \\ Eesti Keele ja Kultuuri Instituut \\ Slaavi Keelte ja Kultuuride Instituut \\ Narva mnt 25 \\ 10120 Tallinn \\ EESTI
}


Intertextuality and National Literatures in the Context of Comparative Literature Research

\section{References}

Anni, A. 1922. Eino Leinost. - E. Leino, Helkalaulud. Eestistanud ja sissejuhatuse kirjutanud August Anni. Tartu: Eesti Kirjanduse Seltsi Koolikirjanduse toimkonna kirjastus, 5-14.

Bloom, H. 1975. The Anxiety of Influence. A Theory of Poetry. New York: Oxford University Press.

Burnett, L. 2002. Cultural Continuities? - E. Salines, R. Udris, eds., Intertextuality and Modernism in Contemporary Literature. Dublin: Philomel, 40-65.

Eliot, T.S. 1997. Valitud esseid. Tallinn: Hortus Litterarum.

Kristeva, J. 1980. Word, Dialogue, and Novel. - L. S. Roudiez, ed., Desire in Language. A Semiotic Approach to Literature and Art by Julia Kristeva. New York: Columbia University Press, 64-91.

Genette, G. 1997. Palimpsests. Literature in the Second Degree. Trans. by C. Newman and C. Doubinsky. Lincoln, London: University of Nebraska Press.

Laanes, E. 2009. Lepitamatud dialoogid. Subjekt ja mälu nõukogudejärgses eesti romaanis. Tallinn: Underi ja Tuglase Kirjanduskeskus

Lachmann, R. 1997. Memory and Literature. Intertextuality in Russian Modernism. Minneapolis, London: University of Minnesota Press.

Lange, A., ed., 2002. Kuus eesti luuletajat Ants Orase tõlkes. Six Estonian Poets in translations of Ants Oras. Tallinn: Tänapäev.

Mihkelev, A. 2011. Between Traditions and Innovations: Tensions in Modernist Art at the Beginning of the $20^{\text {th }}$ Century. - Interlitteraria, 16 (1), 123-136.

Mihkelson, E. 2001. Ahasveeruse uni. Tallinn: Tuum. http://www.estlit.ee/elis/?cmd=writer\&id=86312\&txt=83261 (24.03.2014)

Oras, A. 1963. Estonian Literary Reader. A Brief Survey of Estonian Literature 1. Indiana University Publications Uralic and Altaic Series, Vol. 31. Bloomington: Indiana University.

Orr, M. 2003. Intertextuality. Debates and Contexts. Cambridge: Polity.

Surette, L. 1994. The Birth of Modernism. Ezra Pound, T. S. Eliot, W. B. Yeats, and the Occult. Montreal \& Kingston, London, Buffalo: McGill-Queen's University Press.

Süvalep, E. 2003. Gustav Suits. - Estonian Literary Magazine, 16, 16-21.

Trumpener, K. 2006. World Music, World Literature: A Geopolitical View. H. Saussy, ed., Comparative Literature in an Age of Globalization. Baltimore: The Johns Hopkins University Press, 185-202.

Worton, M., Still, J. 1993. Introduction. - M. Worton, J. Still, eds., Intertextuality. Theories and Practices. Manchester, New York: Manchester University Press, 1-44.

Yeats, W.B. 1990. Luulet. Tallinn: Eesti Raamat. 